\title{
Developing Serious Games for 12-16 Year Old Students
}

\author{
Cecilia Sik Lanyi \\ University of Pannonia, Veszprem, Hungary
}

lanyi@almos.uni-pannon.hu

\begin{abstract}
Three serious games were developed for the same age group (12-16 year old students): one for teaching geometry, one for civic education and a third multimedia drug guide to prevent drug use. The software packages have been given a friendly interface so that they are easy to use, even by computer novices. All three of them deliver totally different knowledge; therefore their design is also different. These designs are described in this article and the following questions are investigated: How does design influence students' motivation? How does operational method influence usability?
\end{abstract}

Hungary's borders opened some 20 years ago, and this - besides all of its positive effects - introduced a number of negative tendencies as well. Today, one of the most acute problems is teenager's drug use.

The third tutorial was written for the young. This was the reason we chose a multimedia presentation format. The "Multimedia tutorial drug guide" is available as a CD-ROM. It has been produced with Macromedia Director. It can be used in secondary schools as part of a 'tutor group' or form-teacher's class".

It has been tested by eighth grade students in the following three different ways: (1) individual use of the CD-ROM at home, (2) use of it in the school's computer laboratory and (3) comparing the effectiveness with a class discussion with teacher guidance without using the CD-ROM. The paper also deals with the evaluation of these tests.

Keywords: serious game, multimedia, education, mathematic, civic education, drug, usability.

\section{Introduction}

Three serious games were developed for 12-16 year old students in three different fields. One teaches mathematics, while the subject of the second is civic education and the last turns to drug problems in order to prevent drug use. As an easy-to-use interface is provided for these guides. There are no problems in their use, even for novice computer users. As was mentioned before, the

Material published as part of this publication, either on-line or in print, is copyrighted by the Informing Science Institute. Permission to make digital or paper copy of part or all of these works for personal or classroom use is granted without fee provided that the copies are not made or distributed for profit or commercial advantage AND that copies 1) bear this notice in full and 2) give the full citation on the first page. It is permissible to abstract these works so long as credit is given. To copy in all other cases or to republish or to post on a server or to redistribute to lists requires specific permission and payment of a fee. Contact Publisher@InformingScience.org to request redistribution permission. knowledge covered by the three guides is completely different which obviously leads to different forms of design. The current article describes their design while seeking the answer to two principle questions: How does design influence students' motivation? How do operational methods influence usability? Therefore the third one has been tested by eighth grade students in the following three different ways: (1) individual 
use of the CD-ROM at home, (2) use of it in the school's computer laboratory and (3) comparing the effectiveness with a teacher guided class discussion without using the CD-ROM. The paper deals also with the evaluation of these tests.

The fundamental purpose of producing the CD-ROM "Drug guide" was to furnish every interested person - and among these the most vulnerable group, the teenagers between 14 and 17 years of age - with a guide and some objective information on the dangers of drug use. The prevention of drug use is becoming more and more important in Hungary where drug problems can be found in many places. In preparing this serious game, our main emphasis was not on the question of why drugs are bad. We wanted to provide information on the main classes of drugs, and what their effects and after-effects are. The CD contains an interesting multimedia picture gallery, provides statistical data, gives information on the actual drug legislation, reproduces a few firsthand reports and supplies a number of important addresses. At the same time we kept in mind that the teenagers like to get the information in a modern format. So we used multimedia techniques, permitting easy surfing between the different pieces of information.

There are a lot of people who do not believe in the necessity of such guides, as they state that as long as the general public is convinced that drugs are lethal, and a single marihuana cigarette will make you a heroin addict, one can hope that this will deter anyone from using it, and the statusquo maintained. Reality shows, however, that the number of drug users increases from year to year, despite all the legislation, contra-propaganda and official viewpoint. This leads youngsters to disbelieve the official information and to accept the opinion of those who are already addicts. This is important also for our CD: if a teenager finds out that a marihuana cigarette is not so dangerous as often suggested, he or she will not believe in the danger of harder drugs, either. Therefore our aim was to prepare a CD guide that provides real, objective information.

The use of the CD has been tried out in two eighth grade first schools and one ninth grade high school class. In every class we first tested the children on the use and harmful effects of drugs, then the children were subdivided into three groups. The first group was able to become familiar with the CD-ROM at home; the second group was introduced to the CD-ROM by their teacher at school; the third group had a tutorial at school on "drug use and its dangers", without using the CD. All three groups then had a second test (paper) on the drug question. This paper shows the structure of the CD and analyses the results of the children's test papers.

\section{The Role of Multimedia and Serious Game in Education}

Since multimedia technologies have been sufficiently highly developed, a growing number of colleges and universities are using computer technology to strengthen their classroom teachinglearning process. Various higher educational institutions have developed high-technology electronic multimedia classrooms, and computer-related faculty training programs. Instructional computing is widely used for classroom multimedia digital media presentations and for interactive computer-based training (Lopategui, 1996).

According to Conelly, Kornelius, and Stehle (1999) if higher education does not manage to adapt to the new circumstances in time, many universities will miss out on this revolutionary new de-

parture. It is not only the duty of the universities themselves to use the potential of the new media for innovation and internationalization, it is also the responsibility of the government. Strong support for education policy is needed because of the expense involved in the design of multimedia and Internet-based courses. Far more incentives are needed for the design and implementation of new software in education.

Higher education and most disciplinary areas in universities, including information system departments, are willingly, though sometimes blindly, jumping on to the bandwagon by converting their traditionally taught courses into online courses. Their efforts are often guided by the myths 
floating around in the discourse on the topic. Given the potentially serious ramifications of information systems academics unreflectively enacting the myths related to online education, Sharker and Nicholson (2005) have argued for the need to critically examine the so-called truths being authoritatively set forth in much of the literature. They examined these myths in the context of online education in their own discipline, that of Information Systems. They intended in their paper to stimulate awareness and encourage debate regarding the pedagogical, administrative, economic, and societal implications of this novel though untested form of education as practised in Information Systems as well as in related disciplines.

Koohang and Harman (2005) explored open source as a metaphor for e-learning. They built the case that the e-learning and open source movements are rooted in the constructivist movement and the constructivist movement is itself rooted in the pragmatism and instrumentalism that pervades John Dewey's theories of understanding as applied to learning. As a result, it is recommended that the use of open source as metaphor for e-learning be further explored in three areas: instructional practices, instructional platforms, and instructional philosophy.

The rapid spread of computers makes the dissemination of informatics culture essential. The use of computers has become part of general education, thus any method to bring the subject nearer to the students is gaining in importance.

Virtual Reality (VR) games are popular among children and young people all over the world. "The current global player populations of the three game titles (of dozens) that was studied over the past few years (Lineage I, Lineage II and Word of Warcraft) totals over 9.5 million - a population which rivals, e.g. most US metropolises" (Steinkuehler, 2006). "The computer gaming industry has now surpassed the "Hollywood" film industry in total entertainment market share, and in the USA sales of computer games now outnumber the sale of books."(Lowenstein, 2002) (Doug Lowenstein, President, Interactive Digital Software Association)

There may be real benefits in using games for learning: "...research has shown that learning is much more effective when the student has fun" (Koops, 2003). This is one of the main reason for using games to educate, as much more is learned when the student is enjoying the education. Another reason is that "...computer games provide a good environment for learning because they are able to give instant feedback to the player, which is highly beneficial for learning" (Prensky, 2001).

In the Hungarian National Basic Curriculum informatics has become a specialised subject area. The use of informatics equipment has to be acquired by the students. Multimedia, VR and Internet tutorials might play an important role in this education, as they help understanding of how to use informatics systems. Multimedia products, serious games are well accepted, not only in schools but also in everyday life, and can thus play an important role in disseminating informatics know-how. The "Drug Guide" also helps in this respect, because it discusses questions that interest teenagers, and if the system is properly designed, it shows students what to expect from interactive multimedia tutorial material and they will not be put off if they encounter multimedia CDs of more theoretical subjects.

\section{Design of the Tutorials}

Human Computer Interaction (HCI) is a primary area for innovative, multidisciplinary research in Computer Science and especially in software development (Draper \& Norman, 1984; Seffah \& Andreevskaia, 2003). Nowadays software development is a team process. The team should include not only software engineers, designers, graphic specialists, animators etc. from the development side but also therapists, language teachers, psychologists and doctors from the customer side, if the task is developing rehabilitation software for special needs users. Misinterpretations between these two groups can be avoided by drawing up precise user requirements. This is neces- 
sary because requirement specification and usability (Shneiderman, 1998) are critical parts of the development process as errors made at this stage have an impact on the further stages of development (design and implementation). Software engineers concentrate on software development, or usability experts concentrate on design; they rarely work together (Seffah \& Metzker, 2004; Holzinger, Geierhofer, Ackerl, \& Siegfired, 2005).

Although computers are at the center of interaction design, design is not a subfield of computer science. As well as being distinct from engineering, interaction design does not fit into any existing design fields. If software were something that the computer user just looked at, rather than operated, traditional visual design would be at the center of software design (Bonnie, 1999).

In our laboratory, several multimedia applications were developed which are easy to use. This project employed state of the art Usability Engineering Methods (Seffah \& Andreevskaia, 2003; Seffah \& Metzker, 2004), which had been determined through a process of User Centered Development (Seffah \& Andreevskaia, 2003; Holzinger et al., 2005).

We have used the Macromedia "Multimedia Director" program to establish our application as this enabled easy implementation of interactivity, inclusion of animations, video-clips and audiosound effects.

Having the broadest possible group of users in mind, we endeavoured to limit the necessary computational need.

\section{The Civic Education Multimedia Tutorial}

The screen design of the civic education multimedia tutorial is closely linked to the topic of the education material (Figures 1 and 2). It contains not only Hungarian-related civic issues, but knowledge on the European Union as well. As far as its structure is concerned, the education software has been designed in such a way as to allow later expansion as new and modified laws come into civic life. This feature ensures up-to-date knowledge for users of the guide at any time.

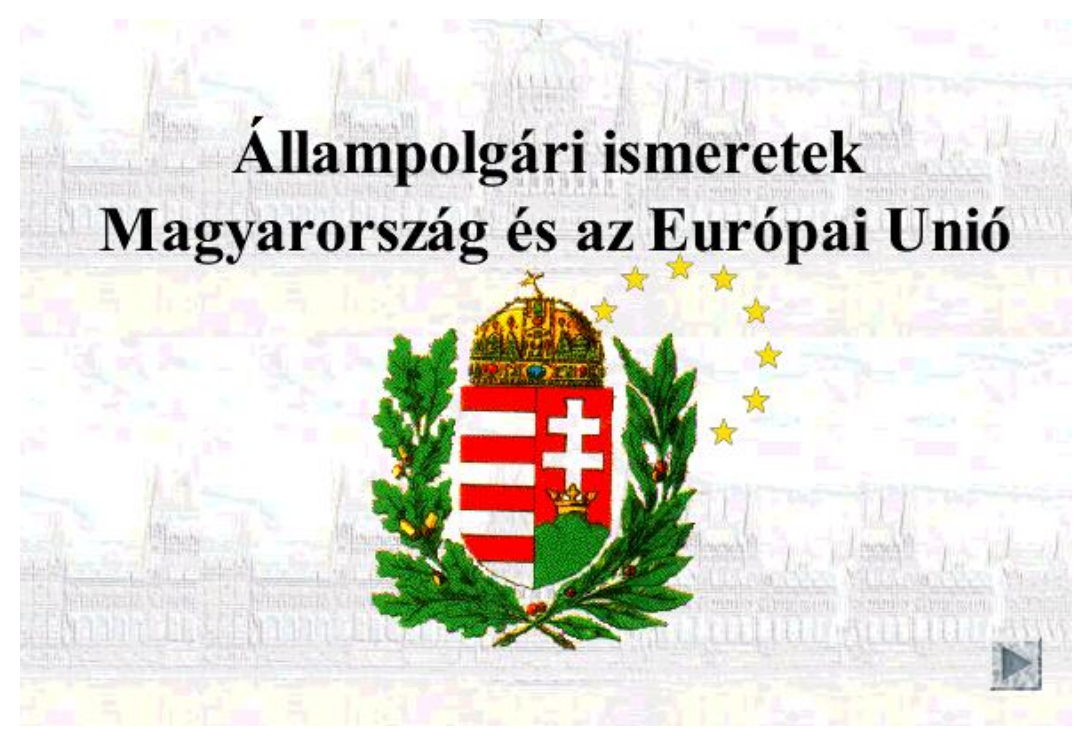

Figure 1: The first page of civic education multimedia tutorial: Hungary and the EU 


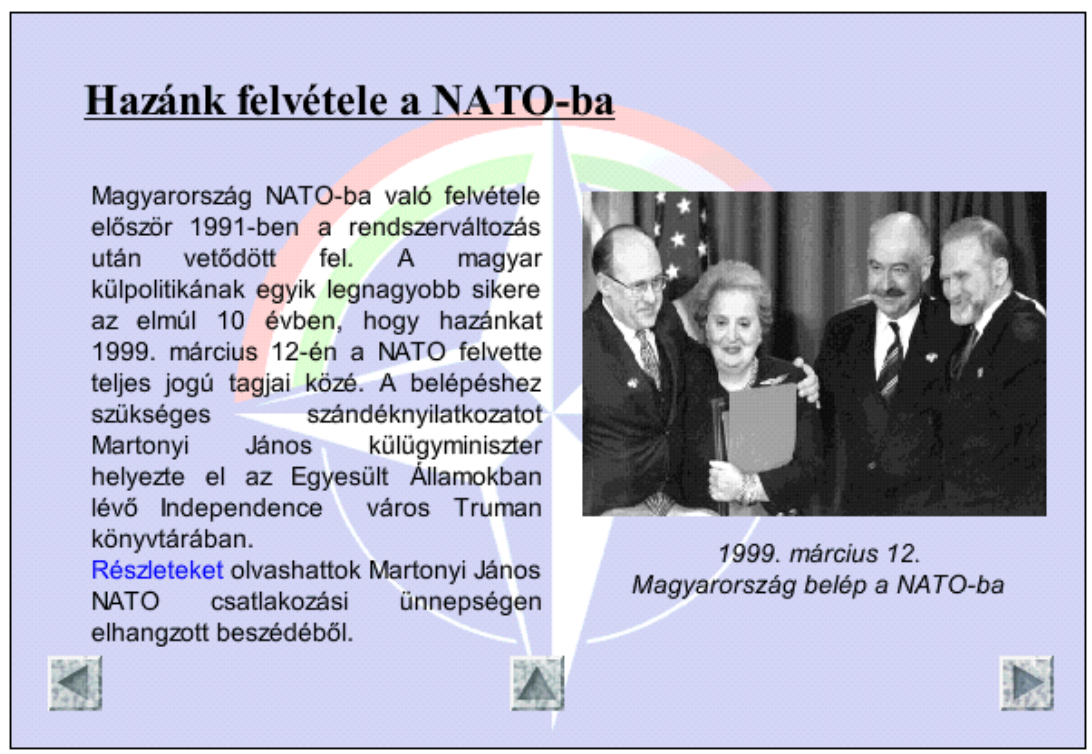

Figure 2: Hungary joins NATO

The Civic guide was tested in the 8th grade in two elementary schools (13-14 years old students). We assessed the pupils a priori knowledge on civics with a test, then divide them into two groups. The first group contained 25 pupils who discussed civics collectively with a teacher and were also asked to look up certain sections in the multimedia guide. The second group of 23 students also debated civic issues with a teacher in class, but they were not given the multimedia software.

The assessment after the seminars dealt with three fields: 23 questions on general civics, 19 on the European Union, and 6 on private opinions, one point for each one. The findings from the test (Table 1) showed that teaching civics with digital support is more motivating than standard teaching.

\begin{tabular}{|l|r|r|}
\hline \multicolumn{2}{|c|}{ Table 1: Average scores } \\
\hline & \multicolumn{1}{|l|}{ With the game } & Without the game \\
\hline Civic knowledge before seminars & 12.12 & 11.27 \\
\hline Civic knowledge after seminars & 15.08 & 14.18 \\
\hline EU knowledge before seminars & 7.21 & 7.00 \\
\hline EU knowledge after seminars & 11.36 & 10.47 \\
\hline
\end{tabular}

It can be claimed that studying with the Civics guide increases knowledge slightly more than the "only-discuss" seminar. The results were analysed with a t-test. Significant differences were found only between the scores before and after the seminars, but no difference was found between the two groups. Then it obviously follows that both studying forms increased the civic 
knowledge. The scores of the group with multimedia support were a bit higher: 0.05 point more in civic questions and 0.7 on EU knowledge. It can be stated that multimedia supported learning increased knowledge more, although only slightly, and, which is obvious, was more interesting and motivating for youngsters than ordinary teaching.

\section{Teaching Geometry}

The screen design of this guide also fits the topic. In the main menu two pathways open for the user: one leads to the plane figures, the other to the solids. The first submenu contains the circumference and area of plane figures, while the second describes the surface area and content of solids (Figure 3).

Every new section starts with a playful introduction, then discussion and direct teaching exercises follow. Since the program is interactive, there is no strict order for browsing the sections; the users can choose their own pace and direction through the teaching material provided while following certain instructions.

Navigation can be conducted via well-defined buttons, images and icons. More complex objects and phenomena in 3D space, which are hard to comprehend, are also shown through animations for better understanding. Visual presentation is needed particularly where prior experience of the students is missing or to depict formerly unseen elements.

But not only this surface level needs to form an interesting and exciting display, the deep construction of the whole multimedia-enhanced teaching material should attract students into an experimental type of learning. This is the point where multimedia and digital technologies are particularly useful: through hyperlinks, interactivity and the multimodal nature students are more easily encouraged to deal actively with the teaching material. These features were exploited in the following way in our software.

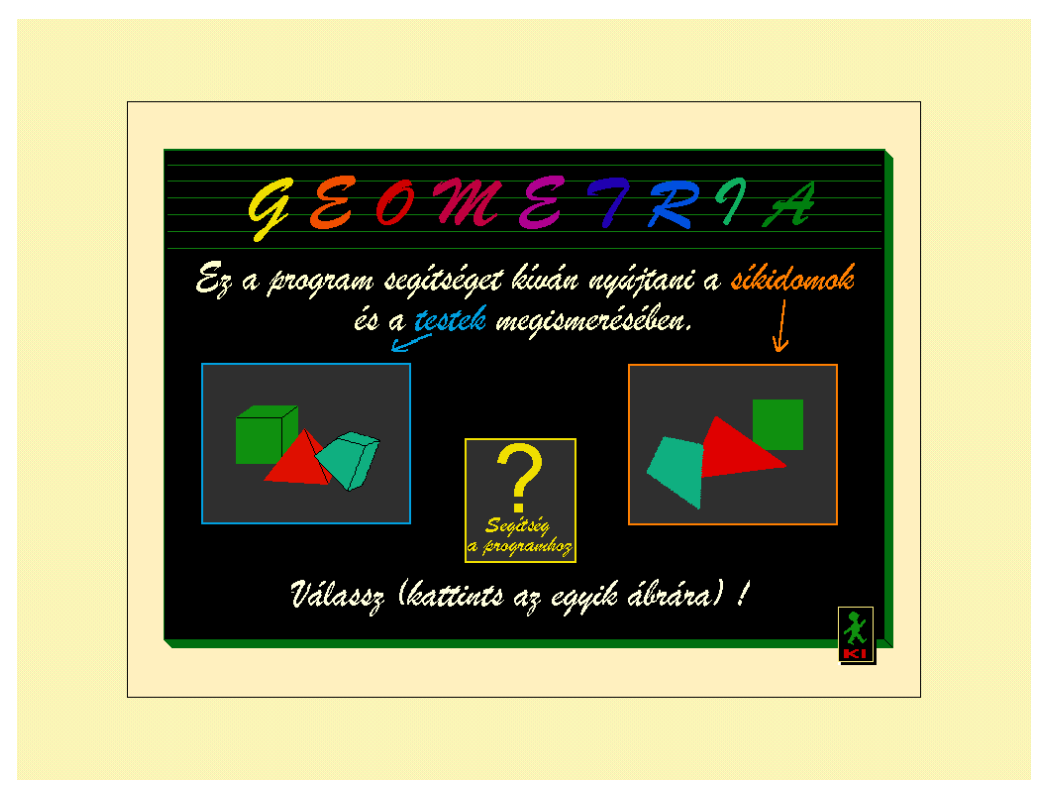

Figure 3: The first page of the "Geometry" serious game 
A page contains only a small amount of commentary, with suitable pastel-shades. New pieces of information to learn are softly highlighted, and illustrated through figures or even animation if needed - for example in the case of the content of a solid.

The multimedia guide to basic geometry was tested with a subject group of 162 pupils in a similar way to the test of the "Civics Guide". But this time the subject group was more heterogeneous: a class with a mathematics specialisation and another one with no such specialisation both in the $6^{\text {th }}$ and $8^{\text {th }}$ grades of elementary school (12-14 years old students) were measured. They had a written test before and after studying with the multimedia guide. Table 2 depicts their performance and the results of the t-test.

\begin{tabular}{|c|c|c|c|c|c|c|}
\hline \multicolumn{7}{|c|}{ Table 2: Correlation and T-probe of the tests } \\
\hline \multirow[b]{2}{*}{ Geometry score } & \multirow{2}{*}{ Average } & \multirow{2}{*}{$\begin{array}{l}\text { Numb. of } \\
\text { partic. }\end{array}$} & \multirow{2}{*}{$\begin{array}{l}\text { Standard } \\
\text { deviation }\end{array}$} & \multicolumn{2}{|c|}{ correlation } & \multirow{2}{*}{$\begin{array}{l}\text { t-test sig- } \\
\text { nifi-cance }\end{array}$} \\
\hline & & & & $\begin{array}{l}\text { Corre- } \\
\text { lation }\end{array}$ & $\begin{array}{l}\text { Signifi- } \\
\text { cance }\end{array}$ & \\
\hline \multirow{2}{*}{$\begin{array}{l}\text { 1. mc } 6 \text { beforeCD } \\
\text { mc } 6 \text { after CD }\end{array}$} & 3.59 & 34 & 1.08 & \multirow[t]{2}{*}{0.55} & \multirow[t]{2}{*}{0.001} & \multirow[t]{2}{*}{0.70} \\
\hline & 3.71 & 34 & 2.11 & & & \\
\hline \multirow{2}{*}{$\begin{array}{c}\text { 2. mc } 8 \text { beforeCD } \\
\text { mc } 8 \text { after }\end{array}$} & 6.98 & 40 & 1.63 & \multirow[t]{2}{*}{0.62} & \multirow[t]{2}{*}{0.000} & \multirow[t]{2}{*}{0.001} \\
\hline & 5.99 & 40 & 2.11 & & & \\
\hline \multirow{2}{*}{$\begin{array}{c}\text { 3. nmc } 6 \text { beforeCD } \\
\text { nmc } 6 \text { after }\end{array}$} & 3.24 & 33 & 1.82 & \multirow[t]{2}{*}{0.52} & \multirow[t]{2}{*}{0.002} & \multirow[t]{2}{*}{0.44} \\
\hline & 3.55 & 33 & 2.54 & & & \\
\hline \multirow{2}{*}{$\begin{array}{l}\text { 4. nmc } 8 \text { beforeCD } \\
\text { nmc } 8 \text { after CD }\end{array}$} & 3.17 & 42 & 2.41 & \multirow[t]{2}{*}{0.66} & \multirow[t]{2}{*}{0.000} & \multirow[t]{2}{*}{0.89} \\
\hline & 3.12 & 42 & 2.86 & & & \\
\hline \multirow{2}{*}{$\begin{array}{l}\text { 5. sum c } 6 \text { before CD } \\
\text { sum c } 6 \text { after CD }\end{array}$} & 3.42 & 67 & 1.49 & \multirow[t]{2}{*}{0.52} & \multirow[t]{2}{*}{0.000} & \multirow[t]{2}{*}{0.39} \\
\hline & 3.63 & 67 & 2.32 & & & \\
\hline \multirow{2}{*}{$\begin{array}{c}\text { 6. sum c } 8 \text { before CD } \\
\text { sum c } 8 \text { after }\end{array}$} & 5.02 & 82 & 2.81 & \multirow[t]{2}{*}{0.75} & \multirow[t]{2}{*}{0.000} & \multirow[t]{2}{*}{0.02} \\
\hline & 4.52 & 82 & 2.89 & & & \\
\hline
\end{tabular}

mc 6: mathematics faculty 6th grade class, $\mathrm{mc} 8$ : mathematics faculty 8 th grade class nmc 6: non mathematics faculty 6 th grade class, nm8o: non mathematics faculty 8 th grade class sum c 6: summa 6th class sum c 8: summa 8th class

As can be seen from Table 2, the 8th grade students scored less in the second test than in the first. The t-test denoted significant differences $(\mathrm{p}<0.05)$ there. Another interesting fact is that the mathematics specialisation students performed worse in the second test.

Judging from these experiences, the following conclusions could be drawn: learning with the support of the Serious Game to Geometry suited the $6^{\text {th }}$ grade students with or without a mathematics specialisation. But it did not suit $8^{\text {th }}$ grade students regardless of whether they had a mathematics specialisation. This may have been a consequence of their greater maturity and instead of a collective learning they should have explored the game individually. 


\section{The "Drug-Guide" Serious Game}

\section{Exterior Appearance}

Even at the design of the CD the exterior appearance of the product was kept in mind. We studied the preference of those for whom we intended to prepare the guide: Thus, many lively colours were used, with attention to contrast as well. Two classes of fonts were selected: for main headings, menu-points fonts were used that are now "in", sometimes perhaps even extravagant (Figure 4-5-6). For main text fonts were selected that are of a more classical character and are easy to read.

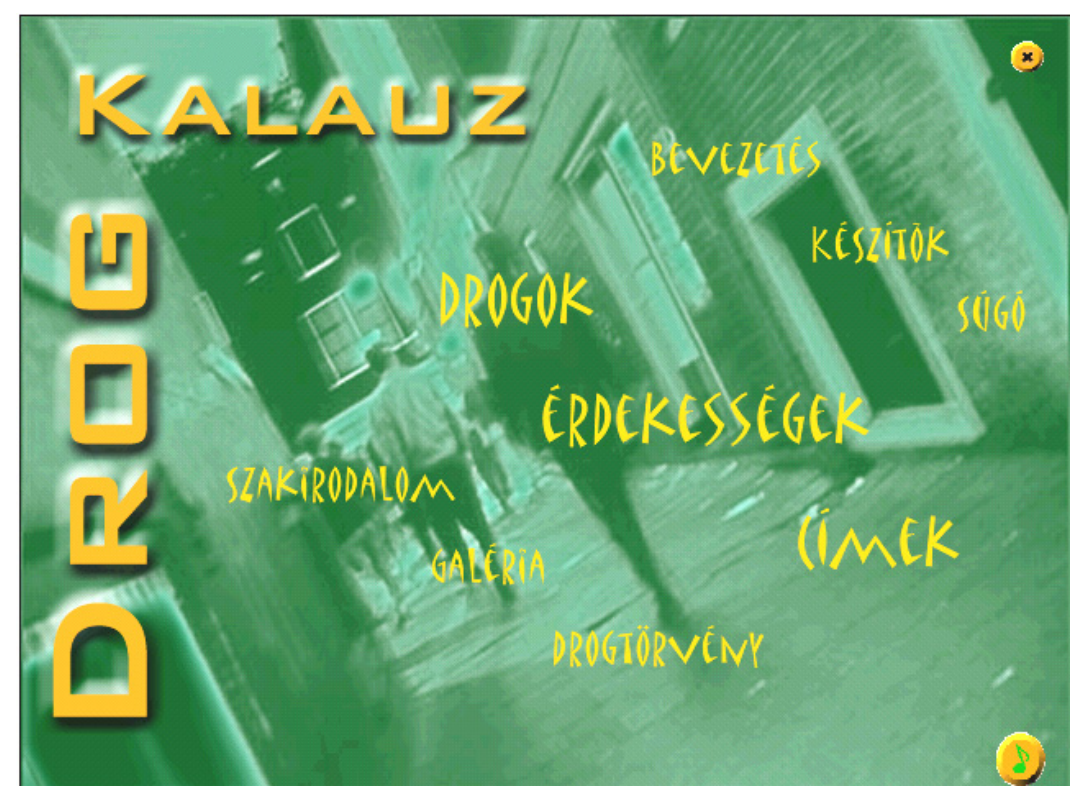

Figure 4: The main menu of the "Drug-Guide"

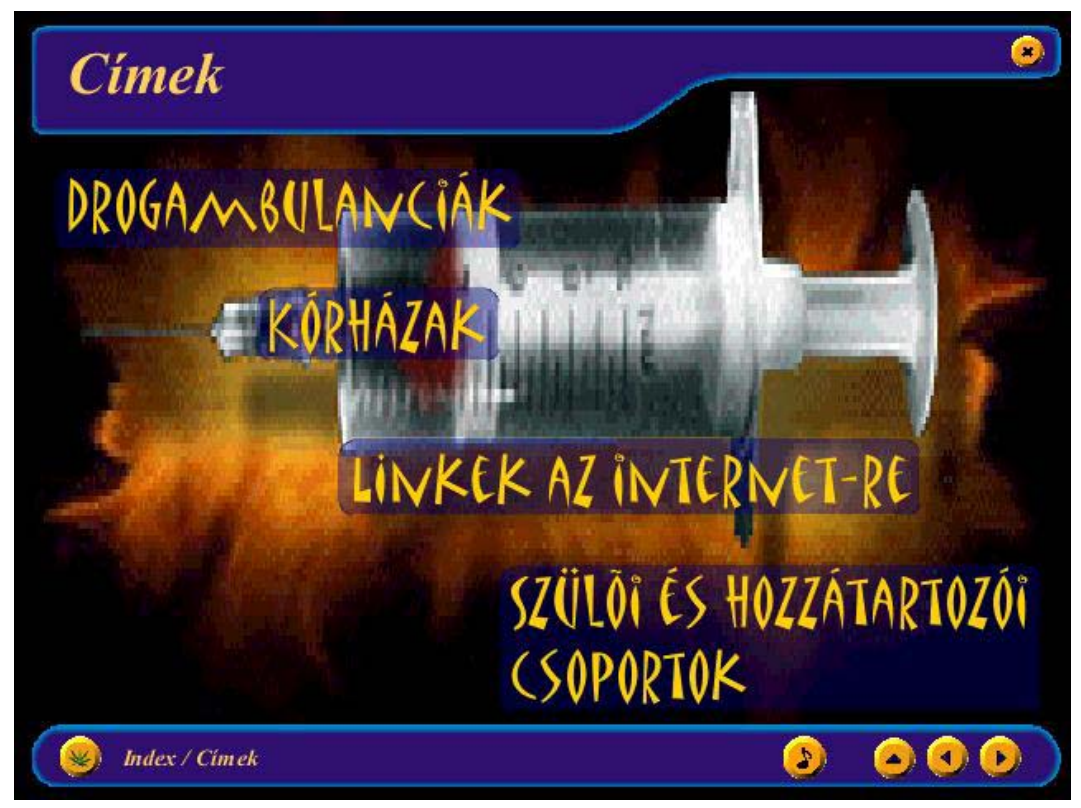

Figure 5: Useful links sub menu form the "Drug-Guide" 
Music used to underline the text has been selected according to the preference of the age group for whom the $\mathrm{CD}$ was prepared. Naturally care has to be taken not to upset the somewhat older listener. As an extreme remedy the sound can always be cut off at any time.

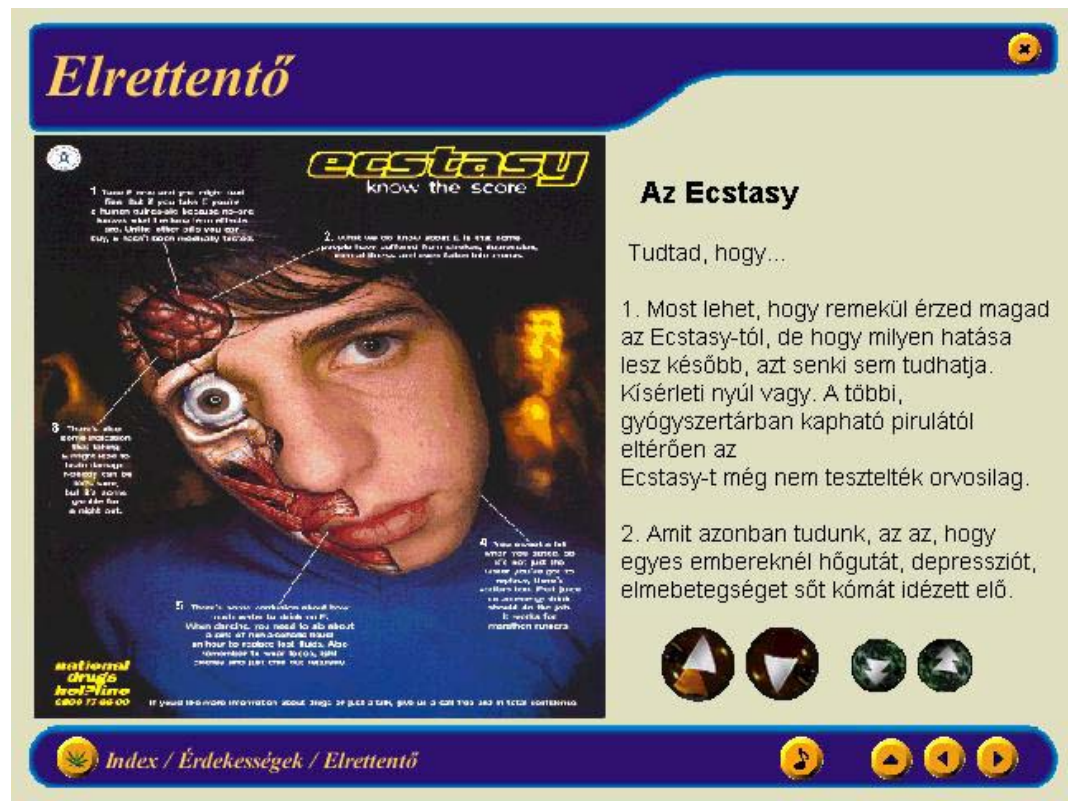

Figure 6: Deterrent sub menu from the "Drug-Guide"

\section{Structure}

The sections of the "Drug Guide" build a cascading tree structure. One can roam upwards and downwards through any level or return directly to the main menu. The maximum depth of the structure is four, thus with maximum of four clicks one can get from any place to any other location. Exploring downwards is done from a menu, and there is a special button for getting back to the starting point from any point in the structure. In some cases one can explore also at the same level, in such cases there appear small lamps with "go left" and "go right" buttons on the screen. Figure 7 contains the complete tree structure. 


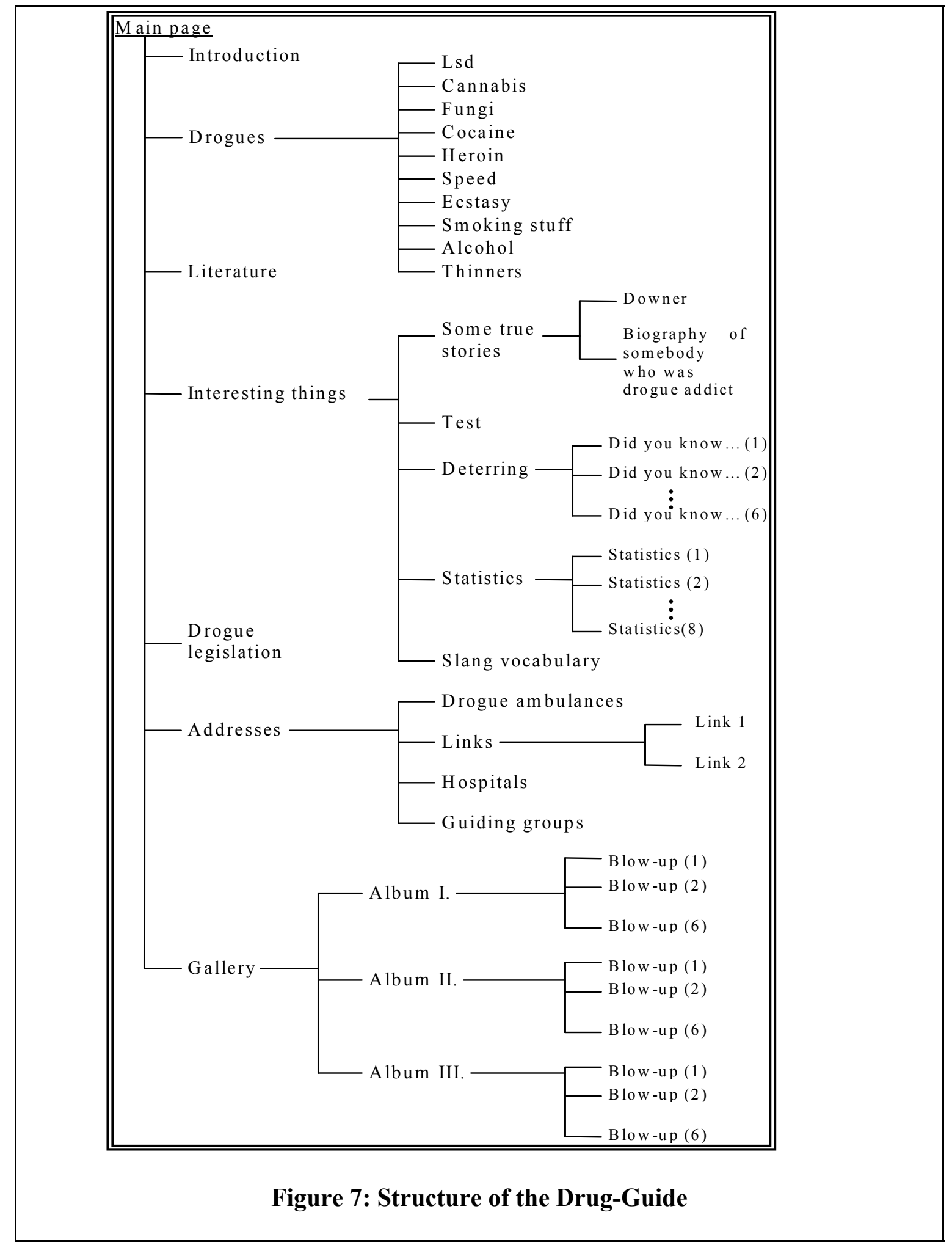




\section{The Use and the Evaluation of the "Drug-Guide" Serious Game}

Although many teachers are of the opinion that one cannot start drug discussion early enough with pupils (some 11-12 year olds already try smoking and alcohol), but our intention was to introduce the "Drug Guide" approximately at the eighth and ninth grades. (With the present school system in Hungary there are many children who follow a basic education system up to the eighth grade and there is another group which starts high-school education at the ninth grade.) Our Drug Guide was intended for these students, as these are the age groups where some students might also encounter hard drugs.

The use of computerised information was felt to be an advantage by all teachers, because students like information supplied by modern means. We have received feed-back from teachers that the material we have covered was interesting, not only for the pupils but also for the teachers, as it helped them to orient themselves in the field of drugs.

The "Drug Guide" CD has been tested in two eighth grade basic education classes and one ninth grade (high-school=secondary school class 1 .) (14-16 years old students) class. In every class, there was first a written test on drugs, then every class was subdivided into three groups. In the first group of children could use the Drug Guide CD at home, in the second group they studied the CD-ROM at the school's informatics laboratory, where they had some help from the teacher in charge. In the third group the teacher discussed with the students the drug question in a classical form, without the help of the CD-ROM (Table 3). After this, students had to take a second written test (Table 4).

The test dealt with four groups of questions: smoking, alcohol, knowledge about drugs (in summary 26 questions). The fourth section dealt with their opinion of drugs and of trying drugs (six questions).

\begin{tabular}{|l|r|r|r|r|r|r|r|}
\hline \multicolumn{8}{|c|}{ Table 3: Number of pupils participating in the experiment } \\
\hline & \multicolumn{1}{|c|}{ Alone at home } & \multicolumn{1}{|c|}{ At school with CD } & \multicolumn{1}{|c|}{ At school without CD } & In summary \\
\cline { 2 - 6 } & boy & girl & boy & girl & boy & girl & \\
\hline $1^{\text {st }}$ school & 5 & 4 & 4 & 5 & 7 & 7 & 32 \\
\hline $2^{\text {nd }}$ school & 4 & 0 & 4 & 6 & 7 & 5 & 26 \\
\hline $3^{\text {rd }}$ school & 5 & 5 & 3 & 4 & 0 & 9 & 26 \\
\hline Total: & 14 & 9 & 11 & 15 & 14 & 21 & 84 \\
\hline
\end{tabular}

\begin{tabular}{|c|c|c|}
\hline \multicolumn{3}{|c|}{ Table 4: Average scores of the first test } \\
\hline max. $=26$ & boy & girl \\
\hline $1^{\text {st }}$ school & 14.69 & 14.75 \\
\hline $2^{\text {nd }}$ school & 15.17 & 15.15 \\
\hline $3^{\text {rd }}$ school & 17.22 & 16.15 \\
\hline
\end{tabular}

Results were examined by t-test and correlation analysis. Significant differences $(p<0.05)$ were only found between pupils using and not using the $\mathrm{CD}$. There was no difference between pupils using CD at home and at school (Tables 4, 5, 6, and 7). This implies that our serious game is a more efficient educational tool than just speaking about drugs. There was no significant correlation between drug attitude and knowledge (Tables 8 and 9). 


\begin{tabular}{|c|r|r|r|r|r|r|}
\hline \multicolumn{7}{|c|}{ Table 5: Average scores of the second test } \\
\hline \multirow{2}{*}{ max.=26 } & \multicolumn{2}{|c|}{ Alone at home } & \multicolumn{2}{|c|}{ At school with CD } & \multicolumn{2}{|c|}{ At school without CD } \\
\cline { 2 - 7 } & boy & girl & \multicolumn{1}{c|}{ boy } & girl & boy & girl \\
\hline $1^{\text {st }}$ school & 17.6 & 21 & 22.75 & 21.4 & 19.29 & 17.29 \\
\hline $2^{\text {nd }}$ school & 18.25 & - & 16.25 & 15.56 & 15.2 & 15.3 \\
\hline $3^{\text {rd }}$ school & 18 & 16.25 & 17.5 & 18.5 & & 17 \\
\hline
\end{tabular}

\begin{tabular}{|c|r|r|}
\hline \multicolumn{3}{|c|}{ Table 6: Attitude scores of the first test } \\
\hline max. $=20$ & \multicolumn{1}{|c|}{ boy } & \multicolumn{1}{|c|}{ girl } \\
\hline $1^{\text {st }}$ school & 14.62 & 16 \\
\hline $2^{\text {nd }}$ school & 13.7 & 14.7 \\
\hline $3^{\text {rd }}$ school & 15.78 & 17.06 \\
\hline
\end{tabular}

\begin{tabular}{|l|r|r|r|r|r|r|}
\hline \multicolumn{7}{|c|}{ Table 7: Attitude scores of the second test } \\
\hline \multirow{2}{*}{ max.=20 } & Alone at home & \multicolumn{2}{|c|}{ At school with CD } & \multicolumn{2}{|c|}{ At school without CD } \\
\cline { 2 - 8 } & boy & girl & boy & girl & boy & girl \\
\hline $1^{\text {st }}$ school & 16.6 & 16.25 & 17 & 16.5 & 15.14 & 16.21 \\
\hline $2^{\text {nd }}$ school & 14.25 & - & 15 & 16.33 & 14 & 15 \\
\hline $3^{\text {rd }}$ school & 19 & 18 & 16 & 18 & - & 17.5 \\
\hline
\end{tabular}




\begin{tabular}{|c|c|c|c|c|c|c|c|c|c|c|}
\hline \multicolumn{11}{|c|}{ Table 8: The students' opinion before and after the learning } \\
\hline \multirow{2}{*}{$\begin{array}{c}\text { State- } \\
\text { ment } \\
(\%)\end{array}$} & \multicolumn{2}{|c|}{ I fully agree } & \multicolumn{2}{|c|}{ I agree } & \multicolumn{2}{|c|}{ I have no opinion } & \multicolumn{2}{|c|}{ I disagree } & \multicolumn{2}{|c|}{ I totally disagree } \\
\hline & boy & girl & boy & girl & boy & girl & boy & girl & boy & girl \\
\hline \multirow[t]{2}{*}{ A } & 11.1 & 7.5 & 13.9 & 2.5 & 9.3 & 8.5 & 18.5 & 21.5 & 47.2 & 60 \\
\hline & 0 & 0 & 7.1 & 0 & 18.8 & 12.3 & 19.4 & 25 & 54.7 & 62.7 \\
\hline \multirow[t]{2}{*}{ B } & 23.8 & 13.7 & 19 & 17.6 & 16.8 & 9.9 & 9.5 & 23.5 & 30.9 & 35.3 \\
\hline & 30.6 & 12.5 & 13.9 & 22.5 & 13.8 & 17.5 & 13.9 & 17.5 & 27.8 & 30 \\
\hline \multirow[t]{2}{*}{$\mathrm{C}$} & 7.1 & 1.9 & 7.1 & 11.7 & 19.2 & 16.1 & 38 & 39 & 28.6 & 31.3 \\
\hline & 13.9 & 0 & 11.1 & 10 & 8.3 & 30 & 38.9 & 30 & 27.8 & 30 \\
\hline \multirow[t]{2}{*}{ D } & 55.6 & 82.5 & 5.56 & 10 & 30.5 & 5 & 0 & 0 & 8.3 & 2.5 \\
\hline & 61.8 & 68.6 & 19 & 21.5 & 5 & 8 & 4.7 & 0 & 9.5 & 1.9 \\
\hline \multirow[t]{2}{*}{$\mathrm{E}$} & 7.1 & 0 & 0 & 1.9 & 17.3 & 4.1 & 11.9 & 15.6 & 61.8 & 78.4 \\
\hline & 8.3 & 0 & 8.3 & 5 & 5.5 & 2.5 & 5.6 & 2.5 & 72.3 & 90 \\
\hline \multicolumn{11}{|c|}{$\begin{array}{l}\text { A: Smoking is good and not dangerous } \\
\text { B: In my opinion it is unjust that teenagers below } 18 \text { years of age are not permitted to buy cigarettes } \\
\text { C: Alcohol cannot be a gift, it can be purchased in many shops } \\
\text { D: I would not try a drug, not even if suggested by my best friend } \\
\text { E: I do not see any problem if somebody uses drugs from time to time } \\
\text { Upper row: The students opinion before the learning } \\
\text { Lower row: The students opinion after the learning }\end{array}$} \\
\hline
\end{tabular}

\begin{tabular}{|l|r|r|r|r|r|r|}
\hline \multicolumn{7}{|c|}{ Table 9: Number of pupils who experienced drugs } \\
\hline \multirow{2}{*}{ Statement } & \multicolumn{2}{|c|}{$1^{\text {st }}$ school } & \multicolumn{2}{|c|}{$2^{\text {nd }}$ school } & \multicolumn{2}{|c|}{$3^{\text {rd }}$ school } \\
\cline { 2 - 8 } & 17 boy & 18 girl & 16 boy & 16 girl & 9 boy & 17 girl \\
\hline Have you ever smoked a cigarette? & 11 & 10 & 15 & 7 & 8 & 11 \\
\hline Have you ever drunk alcohol? & 17 & 15 & 16 & 11 & 9 & 17 \\
\hline Have you ever taken drugs? & 4 & 1 & 1 & 0 & 1 & 0 \\
\hline
\end{tabular}

\section{Summary}

During the tests - as a result of professional advice from teachers - we improved the program. Within this project, state of the art Usability Engineering Methods (Holzinger, 2001, 2005) were used which have been acquired in User Centered Development (Holzinger, 2001; Karat, 1997). Last but not least our other major point was the testing. There are many methods for studying usability, but the most basic and useful is user testing (Nielsen, n.d.a). Big computer companies have been known to invest in million-dollar usability labs, but most everyday usability projects are cheap (Nielsen, n.d. b). Our programs have been tested by students in the age group (12-16 years), in several schools, where an efficiency test was also made with control groups. Both the students and teachers were happy to participate in our project and get our software free of charge. In this way we were able to develop user friendly serious games for students in different fields of education. 
Drug use is becoming an acute question in Hungary nowadays. Teenagers are the most vulnerable group in this respect.

As with most other addictions the best remedy is proper prevention. Nobody becomes a drug addict by chance, the first experimentation is usually without physical pressure. The problem is rooted very deeply in the socio-economic situation. The present serious game does not discuss the question in its full breadth, only a small segment of the question has been studied. The aim was to prepare material that presents information for a teenage group in a modern form that will attract their attention.

The "Drug Guide" has been prepared with young readers in mind, therefore a multimedia form was selected. Possibilities offered by Macromedia Director were used. The application should be easy to use also by non computer experts. It was intended for school and home use.

The pedagogical evaluation of the serious game showed that its use can help to deter students effectively from drug use.

\section{References}

Bonnie, M. (1999). Defining interactive multimedia design education: Expanding the boundaries, Proceeding of Eurographics Workshop, Computer Graphics and Visualization Education July 3-5, 1999, Coimbra, Portugal, 191-196.

Conelly, M., Kornelius, J., \& Stehle, C. (1999). Virtual seminars: Designing ESP translation classes. in AREAS - Annual Report on English and American Studies. Bd. 17. Trier 1999, 337-364.

Draper, S. W., \& Norman, D. A. (1984). Software engineering for user interfaces. $7^{\text {th }}$ International Conference on Software Engineering, Orlando, FL, 214-220.

Holzinger, A. (2001). Basiswissen multimedia band 3: Design. Entwicklungstechnische Grundlagen multimedialer Informationssysteme. Würzburg: Vogel

Holzinger, A. (2005). Usability engineering for software developers. Communications of the ACM, 48, 7174.

Holzinger, A., Geierhofer, R., Ackerl, S., \& Siegfired, S. (2005). The user centered development of a new medical image viewer. In J. Zara \& J. Sloup (Eds.), Central European Multimedia and Virtual Reality Conference CEMVRC 2005, 63-68.

Karat, J. (1997). User centered design. Communications of the ACM, 40, 33-38.

Koohang, A., \& Harman, K. (2005). Open source: A metaphor for e-learning. Informing Science: the International Journal of an Emerging Transdiscipline, 8, 75-86. Retrieved from http://inform.nu/Articles/Vol8/v8p075-086Kooh.pdf

Koops, M.C. (2003). Digital adventure game-based learning. Retrieved from http://www.drkoops.nl

Lopategui, E. (1996). Enhancing higher education teaching for the exercise science and health: Trends and developments using instructional computing. Retrieved from http://www.saludmed.com/Informat/Multimed/mm educ.html

Lowenstein, D. (2002). Essential facts about the video and computer game industry. Retrieved from http://www.idsa.com/pressroom.html

Nielsen, J. (n.d.a). Nielsen's Alertbox: Fundamentals and definition. Retrieved from http://useit.com/alertbox/20030825.html

Nielsen, J. (n.d.b). Nielsen's Alertbox: Misconception about usability. Retrieved from http://useit.com/alertbox/20030908.html

Prensky, M. (2001). Digital natives, digital immigrants. On the Horizon, 9(5). NCB University Press, 
Sarker, S., Nicholson, J. (2005). Exploring the myths about online education in information systems. Informing Science: the International Journal of an Emerging Transdiscipline, 8, 55-73, from http://inform.nu/Articles/Vol8/v8p055-073Sarker.pdf

Seffah, A., \& Andreevskaia, A. (2003). Empowering software engineers in human-centered design. $25^{\text {th }}$ International Conference on Software Engineering, Portland, 653-658.

Seffah, A., \& Metzker, E. (2004). The obstacles and myths of usability and software engineering. Communication of the ACM, 47(12), 71-76.

Shneiderman, B. (1998). Design the user interface. Addison-Wesley, 95-153

Steinkuehler, C. (2006). Massively multiplayer online games - Based Learning. M3 - Interdisciplinary Aspects on Digital Media \& Education, Workshop, Wien, Austria, Nov. 23, 15-16.

Links from the Drug Guide material was collected http://www.newscientist.com/hottopics/marijuana/ http://www.druglibrary.org/

http://www.hyperreal.org/drugs/psychedelics/leary/psychedelic.html

http://www.drugwatch.org/

http://www.lycaeum.org/

http://www.drugtext.org/

Hungarian links:

http://fly.to/funyiro/

http://www.akg.hu/drog/

http://www.sch.bme.hu/korok/filmklub/drog.htm

http://www.sch.bme.hu/korok/filmklub/droglink.htm

http://www.extra.hu/droginfo/

http://www.c3.hu/ drogstop/

\section{Biography}

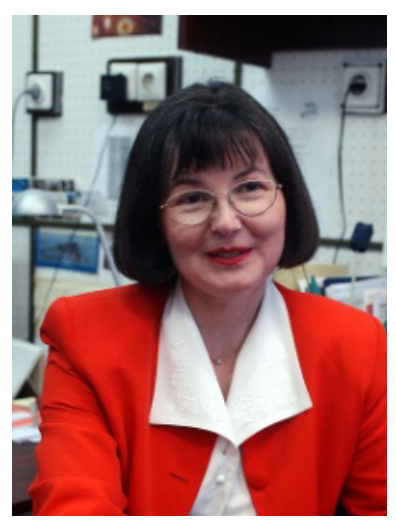

Cecilia Sik Lanyi is associate professor at the University of Pannonia. She studied Mathematics and Computer Science (M.S.) - József Attila University, Szeged (1984), and teacher of mathematics (Berzsenyi Daniel Teacher Training College in 1988). She obtained the degree of Dr. Univ. at the University of Veszprem, Hungary in Physicalchemistry (1993), and of PhD at the University of Veszprém, Hungary in Computer Science (2000). She reads and leads laboratory studies on Multimedia, Virtual Reality, Programming the WEB, User Interface Design, Computer Graphics and Design. Her research area is in Multimedia, Virtual Reality, Human Computer Interaction, Design for All. She was the secretariat manager of EDeAN (www.edean.org) in 2009. 